\title{
Comparison of two commercial vaccines against visceral leishmaniasis in dogs from endemic areas: IgG, and subclasses, parasitism, and parasite transmission by xenodiagnosis
}

\author{
Consuelo Barreto Fernandes ${ }^{a}$, Jairo Torres Magalhães Junior ${ }^{a}$, Clauceane de Jesus ${ }^{a}$, \\ Bárbara Maria Paraná da Silva Souza ${ }^{\mathrm{b}}$, Daniela Farias Larangeiraa ${ }^{\mathrm{a}, \mathrm{c}}$, \\ Deborah Bittencourt Mothé Fraga d,e, Patricia Sampaio Tavares Veras ${ }^{\mathrm{e}}$, \\ Stella Maria Barrouin-Melo ${ }^{\mathrm{a}, \mathrm{c}, *}$ \\ a Laboratory of Veterinary Infectious Diseases, Hospital of Veterinary Medicine (HOSPMEV), Federal University of Bahia (UFBA), Salvador, BA, Brazil \\ ${ }^{\mathrm{b}}$ Laboratory of Cellular and Molecular Biology, HOSPMEV, UFBA, Salvador, BA, Brazil \\ ' Departament of Veterinary Anatomy, Pathology and Clinics of the School of Veterinary Medicine and Zootechny, UFBA, Salvador, BA, Brazil \\ d Departament of Preventive Veterinary Medicine and Animal Production of the School of Veterinary Medicine and Zootechny, UFBA, Salvador, BA, Brazil \\ e Laboratory of Pathology and Bio-Intervention, Gonçalo Moniz Research Center-Oswaldo Cruz Foundation-FIOCRUZ/BA, Salvador, BA, Brazil
}

\section{A R T I C L E I N F O}

\section{Article history:}

Received 28 June 2013

Received in revised form

22 November 2013

Accepted 19 December 2013

Available online 6 January 2014

\section{Keywords:}

Canine immunization

Leishmune $^{\circledR}$ and Leish-Tec ${ }^{\circledR}$

Reactogenicity

Leishmania infantum

Xenodiagnosis

Lutzomyia longipalpis

\begin{abstract}
A B S T R A C T
Background: The incidence of zoonotic canine visceral leishmaniasis (CVL) would decrease if dogs were effectively vaccinated; however, additional data on the efficacy of canine vaccines are required for their approved preventative use.

Purpose: To prospectively evaluate vaccination outcomes using two products commercially available in Brazil, with respect to adverse reactions (reactogenicity), humoral response, disease signs, parasitism, and parasite infectiousness in naturally exposed pet dogs in an endemic area of visceral leishmaniasis (VL).

Methods: From 2010 to 2012, healthy dogs were vaccinated with Leishmune ${ }^{\circledR}$ (50 animals) or Leish$\operatorname{Tec}^{\circledR}$ (50 animals). Each dog was examined to identify clinical signs during peri- and post-vaccination procedures every 2 months for 11 months to identify the presence of parasites or parasite DNA in splenic samples using culturing or PCR, respectively. Levels of anti-Leishmania IgG, IgG1, and IgG2 were quantified in sera by ELISA and infectiousness was assessed by xenodiagnosis.

Results: Adverse effects occurred in 2.2\% (1/45) and 13.0\% (6/46) of the animals in the Leishmune ${ }^{\circledR}$ and Leish-Tec ${ }^{\circledR}$ groups, respectively. IgG levels peaked on the 21 st day following the first dose of Leishmune ${ }^{\circledR}$ and on the 21st day after the second dose of Leish-Tec ${ }^{\circledR}$. The final seropositivity rate for IgG was $32.5 \%$ $(13 / 40)$ and $30.9 \%(13 / 42)$ in the Leishmune ${ }^{\circledR}$ and Leish-Tec ${ }^{\circledR}$ groups, respectively. The Leishmune ${ }^{\circledR}$ group presented higher levels of IgG1 and IgG2 compared to the Leish-Tec ${ }^{\circledR}$ group $(p<0.001)$, and ELISA reactivity in both vaccinated groups was significantly lower $(p<0.001)$ than in infected positive control dogs. Parasitism was observed in $12.2 \%$ (5/41) of the Leishmune ${ }^{\circledR}$ group, and 7.9\% (3/38) of the Leish-Tec ${ }^{\circledR}$ group, with xenodiagnostic transmission rates of Leishmania to Lutzomyia longipalpis of $5.1 \%(2 / 39)$, and $5.4 \%(2 / 37)$, respectively.

Conclusions: No significant differences were observed in dogs vaccinated with Leishmune ${ }^{\circledR}$ or Leish-Tec ${ }^{\circledR}$ with respect to LVC clinical aspects, parasitism, IgG seropositivity, or dog infectiousness. The Leishmune ${ }^{\circledR}$ vaccinated animals presented higher levels of IgG, IgG1, and IgG2. The animals vaccinated with Leish-Tec ${ }^{\circledR}$ exhibited adverse reactions with greater frequency and severity.
\end{abstract}

(c) 2013 Elsevier Ltd. All rights reserved.

\footnotetext{
* Corresponding author at: Departamento de Anatomia, Patologia e Clínicas Veterinárias, Escola de Medicina Veterinária e Zootecnia, Avenida Adhemar de Barros, 500, Salvador, BA, Brasil. CEP: 40170-110. Tel.: +55 713283 6754; fax: +55 $7132836728 /+557132836754$

E-mail address: barrouin@ufba.br (S.M. Barrouin-Melo).
}

\section{Introduction}

In endemic areas of visceral leishmaniasis (VL) the incidence of the disease has been increasing in the last 10 years, and, despite underreported, there are approximately 500,000 new human cases per year [1] in Asia, Europe, Middle East, Africa, and America [2]. The main etiological agent of VL in the Americas is Leishmania infantum whose main vector is the phlebotomine Lutzomyia longipalpis [3]. 
In Brazil, 3894 cases of human VL were confirmed in 2011 [4] and dogs are considered the main reservoir of infection in urban areas [5]. Government attempts to control VL are mainly based on the culling of seropositive dogs. In addition to going against the ethical and philosophical principles of the general population, this procedure has not been able to contain the spread of the disease in the country $[5,6]$. Thus, if immunization is able to prevent the parasite transmission to the vector, the vaccination of dogs could be the primary method for disease control in endemic areas $[7,8]$.

As a result of research into the development of vaccines against canine visceral leishmaniasis (CVL), Brazil has become the first country in the world to offer commercially available vaccines to immunize dogs. In 2003, the vaccine Leishmune ${ }^{\circledR}$ was licensed by the Brazilian Ministry of Agriculture. The immunogen of this vaccine is a fucose-mannose ligand (FML) glycoprotein from Leishmania donovani associated with a saponin-based adjuvant [9-11]. In 2007, the Brazilian Ministry of Agriculture licensed the use of Leish-Tec ${ }^{\circledR}$ vaccine, composed of the $A 2$ antigen, a recombinant amastigote-stage-specific protein of different Leishmania species containing saponin as adjuvant [12-14]. Although both vaccines comply with technical requirements for their registration (2003 and 2007), the inclusion of these vaccines as mass control measure for VL needs further investigations. It is necessary to: (1) distinguish between natural infection by $L$. infantum and vaccinal immune response by serotests; (2) evaluate whether vaccines reduce the incidence of infection and disease in dogs; and (3) obtain unequivocally proof that vaccines are able to block the disease cycle at the vector-parasite transmission stage [15-18].

In this context, the present study evaluates the outcomes of dogs living in an endemic area for VL prospectively and comparatively in response to either available vaccine protocols. Vaccinated dogs were followed-up with respect to vaccine reactogenicity, seroconversion, parasitism, CVL signs, and dog infectiousness by xenodiagnosis.

\section{Methods}

\subsection{Animals, area and ethics}

A total of 180 dogs were pre-selected by being seronegative for anti-Leishmania antibodies in ELISA tests, which is the criteria to immunize dogs as established by vaccine manufacturers and the Brazilian Ministry of Agriculture [17]. Further inclusion criteria were: clinical health status assessed by veterinarians, any age or gender; household in a VL endemic area under the responsibility of a guardian (owner), absence of other infections, and no history of prior vaccination or clinical suspicion for VL. The exclusion criteria were CVL seropositivity, mobility to non-endemic areas, historical or clinical evidence of pathologies of any nature, or prior use of any substance for anti-VL preventive or therapeutic purposes. One hundred out of 180 evaluated dogs were included in the study: 50 were vaccinated with Leishmune ${ }^{\circledR}$, and 50 with Leish$\mathrm{Tec}^{\circledR}$. Nine dogs were excluded from the study due to their moving to non-endemic areas (6/100) and to deaths from other causes (3/100).

Another group of 30 dogs was selected throughout the study period as positive controls for the diagnostic tests and to demonstrate the natural occurrence of canine infection in the area at the same time as of the immunized dogs that were also followed up. These animals showed clinical signs, positivity in parasitological and serological tests for CVL, and were domiciled in residences near the vaccinated dogs.

Since vaccination could achieve high levels of efficacy, we decided not to keep a group of unvaccinated or placebo-receiving dogs for ethical and animal welfare reasons. We thought that as the area was hiperendemic, as stated by local health authorities, the chance of such a group acquiring infection and developing the disease would be very high. Since all dogs were kept in their families, placebo-receiving ones could become infected and thus transmit Leishmania to people meanwhile being between evaluations. Furthermore, CVL prevalence in the same area was $17 \%$ to $18 \%$ in 2003 [19] and reported as $24 \%$ to $41 \%$ in the same period as our study, 2010-2011 [20]. The study area included the municipalities of Lauro de Freitas $\left(12^{\circ} 54^{\prime} \mathrm{S}\right.$ and $\left.38^{\circ} 19^{\prime} \mathrm{W}\right)$ and Camaçari $\left(12^{\circ} 42^{\prime} \mathrm{SE}\right.$ and $20^{\circ} 38^{\prime} \mathrm{W}$ ), which are located at $22 \mathrm{~km}$ and $41 \mathrm{~km}$, respectively, from the capital of Bahia State, Salvador. Camaçari covers an area of $785 \mathrm{~km}^{2}$ with a population of 242,970 inhabitants and 60,000 dogs. Lauro de Freitas covers an area of $49 \mathrm{~km}^{2}$ and has a population of 113,543 inhabitants and 28,000 dogs [21].

The study was approved by the UFBA Institutional Review Board for Animal Experimentation, Protocol No. 19/2011, and was conducted in accordance with Brazilian Federal Law on Animal Experimentation (Law no. 11794) [22]. The animals' guardians expressed their permission in informed consent forms.

\subsection{Commercially available vaccines}

The vaccines were purchased from suppliers in the area studied. The Leishmune ${ }^{\circledR}$ vaccine (Fort Dodge) comes in vials containing lyophilized FML antigen $(1.5 \mathrm{mg})$ and saponin $(0.5 \mathrm{mg})$ for reconstitution in $1 \mathrm{~mL}$ of $0.9 \%$ saline solution at the moment of application [23]. A total of 150 doses were used from lot 004/10.

The Leish-Tec ${ }^{\circledR}$ vaccine (Hertape Calier) comes in ready-to-use flasks containing $0.10 \mathrm{mg}$ of the antigen $\mathrm{A} 2$ and $0.5 \mathrm{mg}$ of saponin in $0.9 \%$ of saline solution $(1.0 \mathrm{~mL})$ [24]. A total of 150 doses were used from lot $011 / 10$.

\subsection{Study design}

This clinical study was designed to cause minimal interference on the actual conditions of a potential target population for a public vaccination campaign. Thus, the selected animals were pets and/or guard dogs living in households with natural exposure to the infection. The vaccine distribution was blinded. However, if the household had more than one dog, both vaccines were equivalently distributed: half of the dogs received Leishmune ${ }^{\circledR}$ and the other half, Leish-Tec ${ }^{\circledR}$. The vaccination was performed in three injections at dose intervals of 21 days, subcutaneously, at the scapulae area, according to manufacturer's instructions.

Because the study was clinical and prospective, the data concerning all the dogs during 11 months were divided into four categories for comparative analysis. All dogs were examined and sampled. Group $1(\mathrm{G} 1, n=30)$ was composed of unvaccinated naturally infected dogs defined as positive controls; Groups 2 (G2, $n=40$ dogs) and group 3 (G3, $n=42$ dogs) were composed of dogs vaccinated with Leishmune ${ }^{\circledR}$ or Leish-Tec ${ }^{\circledR}$, respectively.

Group 4 (G4, n=9) was composed of dogs whose data were analyzed separately, because their ELISA values at the time of the first vaccine dose injection ranged at borderline levels. Among them five dogs were vaccinated with Leishmune ${ }^{\circledR}$, and four with Leish-Tec ${ }^{\circledR}$.

Each vaccinated animal was evaluated seven times over 11 months: immediately before the first $\left(T_{0}\right)$, the second $\left(T_{1}\right)$ and the third $\left(T_{2}\right)$ doses of vaccine; 21 days after the third dose $\left(T_{3}\right)$; and $90\left(T_{4}\right), 180\left(T_{5}\right)$ and $280\left(T_{6}\right)$ days after $T_{3}$. In each evaluation, the dogs were examined and sampled for serotests. The xenodiagnosis and collection of splenic aspirates were performed at the last evaluation $\left(T_{6}\right)$ or earlier, if a dog presented serological or clinical evidence of active infection during the partial evaluations. 


\subsection{Reactogenicity, clinical examination and sampling}

The dogs were monitored for the occurrence of post-vaccination reactions after the first $\left(T_{0}\right)$, second $\left(T_{1}\right)$ and third $\left(T_{2}\right)$ dose injections and up to 21 days after the whole vaccination protocol $\left(T_{3}\right)$. All the animals were clinically evaluated during the first 30 (minimum) and 60 (maximum) minutes following the vaccine injection, for signs of immediate reaction. Each dog owner was instructed to carefully observe the animals during the first eight days after each vaccine dose in order to identify the occurrence of signs of hypersensitivity and other adverse effects, such as edema, localized or diffuse pain, prostration, loss of appetite, lameness, and idiosyncratic signs. Any sign of late reaction presented by the dogs should be registered until the next dose was given, on the twentieth first day after the previous injection.

The search for CVL signs [25] or comorbidities was performed from $T_{0}$ to $T_{6}$ and individually registered. Peripheral blood samples were obtained and processed for serology. Splenic aspirates were collected under sedation with $0.1 \mathrm{mg} / \mathrm{kg}$ acepromazine as described previously [26].

\subsection{Indirect ELISA}

The seropositivity for Leishmania-specific IgG was used to select dogs for vaccination and for the verification of post-vaccination seroconversion. IgG, IgG1, and IgG2 reactivity curves for G2, G3, and G4 were used to monitor the humoral response to Leishmania antigens $\left(T_{1}\right.$ and $\left.T_{6}\right)$. The ELISA technique was adapted as described previously $[26,27]$ by a checkerboard titration using an antigen extracted from a local $L$. infantum strain. Reactions were performed in polystyrene plates (Perkin Elmer ${ }^{\circledR}$ ) with sera dilutions of 1: 500 (IgG and IgG2) and 1:100 (IgG1); secondary peroxidase conjugated antibodies (Bethyl ${ }^{\circledR}$ ) at 1:15,000 (anti-dog IgG, cat $\mathrm{n}^{\circ}$ A40-123P), 1:20,000 (anti-dog IgG2, cat $\mathrm{n}^{\circ} \mathrm{A} 40-121 \mathrm{P}$ ), or 1:2000 (anti-dog IgG1, cat $\mathrm{n}^{\circ} \mathrm{A} 40-120 \mathrm{P}$ ); and optical density (OD) measurements at $492 \mathrm{~nm}$ (Asys ${ }^{\circledR}$ reader). The cutoff values (cutoff $=$ mean $\mathrm{OD}+3 \times S D$ ) were determined with sera from 20 healthy dogs from non-endemic areas for CVL; OD readings of $20 \%$ above or below the cutoff point were considered borderlines. To perform a comparative analysis of the OD values obtained in the different plates, an interplate correction factor (CF) was used, as described previously [28]. The CF was determined by the following formula:

$\mathrm{CF}=\frac{\text { mean OD of the positive control reference plate }}{\text { mean OD of the positive control of each plate }}$

Thus, $\mathrm{ODC}=\mathrm{OD} \times \mathrm{CF}$.

\subsection{Parasite culture}

Spleen samples were cultured in a biphasic blood-agar and Schneider's medium (Sigma) supplemented with 20\% of fetal bovine serum (Gibco BRL) and proceeded as previously described [26].

\subsection{Xenodiagnosis}

Each dog was evaluated by xenodiagnosis to verify if the Leishmania parasites were transmitted from dogs to the phlebotomine vector and this was defined as infectiousness. L. longipalpis specimens have been captured in endemic areas for VL and kept in colony for reproduction in the insectary located at the Laboratory of Infectious Diseases/UFBA. For the xenodiagnosis, insects from F1 offspring were used to guarantee they were free of Leishmania and other pathogens. Standardized receptacles with a fine mesh at one end, containing 40 female and 15 male L. longipalpis vectors, were applied to the inner surface of each dog's ear for $30 \mathrm{~min}$. After the feeding, the phlebotomines were maintained under a fructose solution diet for five days and then killed by low temperature and kept in sterile tubes at $-20^{\circ} \mathrm{C}$ until DNA extraction.

\subsection{PCR for L. infantum infection}

Genomic DNA was extracted from canine spleen samples (Invitrogen ${ }^{\circledR}$ ) and from insects after xenodiagnosis (Promega ${ }^{\circledR}$ ) according to the manufacturer's instructions. The samples were measured by digital spectrophotometry $\left(\right.$ NanoDrop $\left.{ }^{\circledR}\right)$. Procedures and primers used were the forward RV1 (5'-CTTTTCTGGTCCCGCGGGTAGG-3') and the reverse RV2 (5'-CCACCTGGCCTATTTTACACCA-3') for the L. infantum kinetoplast DNA as described previously [28]. Negative controls were DNAaseand RNAase-free water, and DNA from spleen and insects fed in a negative dog. Positive controls of the PCR reaction were DNA extracted from $L$. infantum cultures, spleen samples, and insects fed from an infected dog.

\subsection{Data analysis}

Gender, race, and age frequencies in the vaccinated groups were comparatively analyzed by chi-square tests. Nonparametric Mann-Whitney tests were used to compare serum reactivity of anti-Leishmania IgG, IgG1 and IgG2 between the vaccinated dog groups and with the control group of naturally infected nonvaccinated dogs. The differences were considered significant at $p<0.05$. All statistics were performed using the SPSS v.19.0 (IBM Software, USA) and GraphPad Prism v 5.0 for Windows (GraphPad Software, USA).

\section{Results}

\subsection{Adverse effects and clinical evolution}

The characterization of the dogs accordingly to gender, breed, age, and serological response to Leishmania can be found in Table 1; there were no significant differences with respect to gender, race, and age frequencies between groups either before vaccination or at any points in time. One out of the 45 dogs vaccinated with Leishmune ${ }^{\circledR}(\mathrm{G} 2 / \mathrm{G} 4)$ presented local adverse reactions including pain, edema, and late formation of nodule at the injection site (Table 2). The signs were observed after the third vaccine dose. On the other hand, 6 out of 46 dogs vaccinated with Leish-Tec ${ }^{\circledR}(\mathrm{G} 3 / \mathrm{G} 4)$ showed systemic reactions, such as apathy (66.6\%; 4/6), anorexia (33.3\%; $2 / 6)$, and hyporexia (33.3\%; $2 / 6)$, as well as localized reactions, such as pain $(50 \% ; 3 / 6)$, claudication (50\%; 3/6) and edema (50\%; 3/6) associated with local inflammatory nodules $(33.3 \% ; 2 / 6)$, lasting up to five days after the third dose.

The post-immunization clinical follow-up showed that $92.5 \%$ (37/40) of the animals in G2, 92.8\% (39/42) in G3, and 89\% in G4 (8/9) remained healthy throughout the 11 -month period. Clinical signs of active VL were observed in six (3/G2 and 3/G3) out of seven dogs that became infected during the follow up period after vaccination in these two groups (Table 3 ). In the group of nine dogs that were formerly borderlines (G4), one (11\%) became clinically ill (Table 5). All G1 control animals displayed active CVL, including dermopathy (hyperkeratosis, alopecia, scaling, ulcers, or formation of pustules), mucosal (pallor or congestion), ophthalmopathy (conjunctivitis, uveitis or keratoconjunctivitis sicca), onychogryphosis, weight loss, lethargy, splenomegaly, and/or lymphadenopathy evidence. 
Table 1

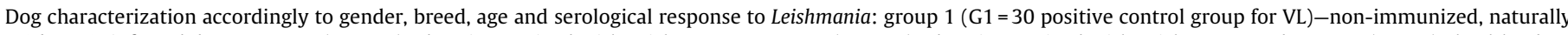

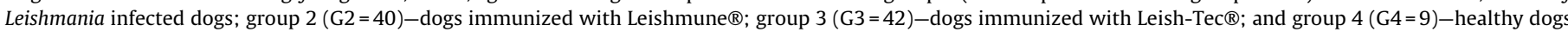
with borderline results to the ELISA cut off values by indirect ELISA (OD between 0.224 and 0.336 ) at the time of the first vaccine injection.

\begin{tabular}{|c|c|c|c|c|}
\hline Character & G1 30 (100\%) & G2 40 (100\%) & G3 42 (100\%) & G4 $9(100 \%)$ \\
\hline \multicolumn{5}{|l|}{ Gender } \\
\hline Male & $13(43.3)$ & $17(42.5)$ & $17(40.5)$ & $1(11.1)$ \\
\hline Female & $17(56.6)$ & $23(57.5)$ & $25(59.5)$ & $8(88.8)$ \\
\hline \multicolumn{5}{|l|}{ Breeds } \\
\hline Mixed breeds & $16(53.3)$ & $19(47.5)$ & $20(47.6)$ & $9(100)$ \\
\hline Rottweiler & $3(10.0)$ & $6(15.0)$ & $10(23.8)$ & 0 \\
\hline German Shepherd & $3(10.0)$ & $2(5.0)$ & $6(14.2)$ & 0 \\
\hline Poodle & $4(13.4)$ & $4(10.0)$ & $2(4.8)$ & 0 \\
\hline Boxer & $2(6.7)$ & $2(5.0)$ & $2(4.8)$ & 0 \\
\hline Labrador & $1(3.3)$ & $2(5.0)$ & $1(2.4)$ & 0 \\
\hline Shepherd Malinois & 0 & $2(5.0)$ & $1(2.4)$ & 0 \\
\hline Doberman & $1(3.3)$ & $1(2.5)$ & 0 & 0 \\
\hline Golden Retriever & 0 & $1(2.5)$ & 0 & 0 \\
\hline Shih-Tzu & 0 & $1(2.5)$ & 0 & 0 \\
\hline \multicolumn{5}{|l|}{ Age (years) } \\
\hline $1-5$ & $14(46.7)$ & $19(47.5)$ & $17(52.4)$ & $3(33.3)$ \\
\hline $6-10$ & $16(53.3)$ & $21(52.5)$ & $20(47.6)$ & $6(66.6)$ \\
\hline ELISA serology (mean of OD readings) & (a) & (b) & (c) & (d) \\
\hline $\operatorname{IgG}$ & 1.760 & 0.341 & 0.291 & 0.580 \\
\hline IgG1 & 1.453 & 0.342 & 0.203 & 0.312 \\
\hline $\operatorname{IgG2}$ & 1.446 & 0.285 & 0.187 & 0.459 \\
\hline Ratio IgG1/IgG2 & 1.00 & 1.20 & 1.09 & 0.68 \\
\hline Ratio IgG/IgG1 & 1.21 & 0.99 & 1.43 & 1.86 \\
\hline Ratio IgG/IgG2 & 1.21 & 1.19 & 1.56 & 1.26 \\
\hline
\end{tabular}

* Dogs with not defined breed.

(a) Mean OD reading in a single assessment, ((b)-(d)) Mean OD readings from $T_{1}-T_{6}$.

Table 2

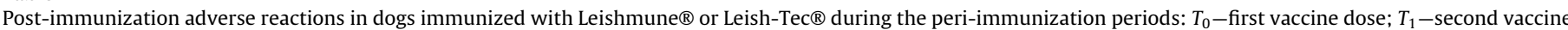
dose 21 days after the first dose; $T_{2}-$ third dose 21 days after the second dose.

\begin{tabular}{|c|c|c|c|c|c|c|}
\hline \multirow[t]{2}{*}{ Reactions } & \multicolumn{2}{|l|}{ First dose $\left(T_{0}\right)$} & \multicolumn{2}{|l|}{ Second dose $\left(T_{1}\right)$} & \multicolumn{2}{|l|}{ Third dose $\left(T_{2}\right)$} \\
\hline & $\begin{array}{l}\text { Leishmune }{ }^{\circledR}(n=45) \\
0 / 45\end{array}$ & $\begin{array}{l}\text { Leish-Tec } ®(n=46) \\
0 / 46\end{array}$ & $\begin{array}{l}\text { Leishmune }{ }^{\circledR}(n=45) \\
0 / 45\end{array}$ & $\begin{array}{l}\text { Leish-Tec } ®(n=46)(a) \\
1 / 46^{*}\end{array}$ & $\begin{array}{l}\text { Leishmune }{ }^{*}(n=45)(\mathrm{b}) \\
1 / 45^{*}\end{array}$ & $\begin{array}{l}\text { Leish-Tec } ₫(n=46)(\mathrm{c}) \\
5 / 46^{*}\end{array}$ \\
\hline Apathy & 0 & 0 & 0 & 1 & 0 & 3 \\
\hline Local pain & 0 & 0 & 0 & 1 & 1 & 2 \\
\hline Local edema & 0 & 0 & 0 & 1 & 1 & 2 \\
\hline Claudication & 0 & 0 & 0 & 1 & 0 & 2 \\
\hline Anorexia & 0 & 0 & 0 & 1 & 0 & 1 \\
\hline Hyporexia & 0 & 0 & 0 & 0 & 0 & 2 \\
\hline Nodule & 0 & 0 & 0 & 0 & 1 & 2 \\
\hline
\end{tabular}

* The results shown are cumulative; the dogs exhibited more than one reaction per vaccine dose.

(a) Duration of reactions: 1 day, (b) Duration of reactions: 2 days, (c) Duration of reactions: 1-5 days.

\subsection{Humoral response}

The cutoff values for serum anti-Leishmania total IgG, IgG1, and $\operatorname{IgG} 2$ by indirect ELISA were $0.280,0.180$, and 0.128 , respectively.

The dogs from G2 (Leishmune $^{\circledR}$ ), G3 (Leish-Tec ${ }^{\circledR}$ ) and G4 (former borderlines that received Leishmune ${ }^{\circledR}$ or Leish-Tec $\left.{ }^{\circledR}\right)$ showed similar median curves for total IgG (Fig. 1A). Peak OD reactivity was observed 21 days after the first vaccine dose $\left(T_{1}\right)$ in the dogs vaccinated with Leishmune ${ }^{\circledR}$. This reactivity was maintained up to 21 days after the three-dose immunization protocols (Fig. 1A). The peak occurred later in the dogs vaccinated with Leish-Tec ${ }^{\circledR}$, at 21 days after the first vaccine booster $\left(T_{2}\right)$ (Fig. $1 \mathrm{~A}$ ). At $T_{1}$ and $T_{2}$, the rate of IgG seroconversion in the Leishmune ${ }^{\circledR}$ group was $57.5 \%$ $(23 / 40)$ and $77.5 \%(31 / 40)$ of the dogs, and in the Leish-Tec ${ }^{\circledR}$ 's it

Table 3

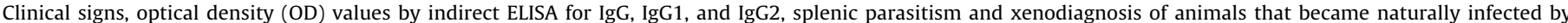
Leishmania during the follow up period after immunization with Leishmune ${ }^{\circledR}$ or Leish-Tec®. Results observed at 11 months post-immunization.

\begin{tabular}{|c|c|c|c|c|c|c|c|c|c|}
\hline \multirow[t]{2}{*}{ Animal } & \multirow[t]{2}{*}{ Vaccine } & \multirow[t]{2}{*}{ Clinical signs } & \multicolumn{2}{|c|}{ Total IgG ELISA } & \multirow[t]{2}{*}{$\operatorname{IgG} 1(\mathrm{OD})^{\mathrm{b}}$} & \multirow{2}{*}{$\frac{\operatorname{IgG} 2}{(\mathrm{OD})^{\mathrm{b}}}$} & \multicolumn{2}{|c|}{ Splenic parasitism } & \multirow[t]{2}{*}{ Xenodiagnosis } \\
\hline & & & (OD) & Result $^{\mathrm{a}}$ & & & Culture & PCR & \\
\hline 1 & Leishmune $\circledR$ & Sores on the tips of the ears, pale mucous & 1.811 & Positive & 1.309 & 1.333 & Positive & Positive & Negative \\
\hline 2 & Leishmune ${ }^{\circledR}$ & Splenomegaly, lymphadenomegaly & 0.319 & Positive & 0.203 & 0.240 & Negative & Positive & Positive \\
\hline 3 & Leishmune ${ }^{\circledR}$ & Absent & 0.269 & Borderline & 0.235 & 0.142 & Negative & Positive & Negative \\
\hline 4 & Leishmune ${ }^{\circledR}$ & Sores on the tips of the ears, pale mucous & 0.282 & Borderline & 0.682 & 0.287 & Negative & Positive & Negative \\
\hline 5 & Leish-Tec ${ }^{\circledR}$ & Lymphadenomegaly, weight loss, pale mucous & 0.906 & Positive & 0.224 & 0.399 & Positive & Positive & Positive \\
\hline 6 & Leish-Tec $®$ & Lymphadenomegaly hyperkeratosis, alopecia & 0.218 & Negative & 0.113 & 0.108 & Negative & Positive & Negative \\
\hline 7 & Leish-Tec $®$ & Splenomegaly, lymphadenomegaly & 0.203 & Negative & 0.111 & 0.075 & Negative & Positive & Positive \\
\hline
\end{tabular}

a IgG cutoff value of 0.280 was considered for serological diagnosis.

b Cutoff values: 0.180 (IgG1); 0.128 (IgG2). 
(A)
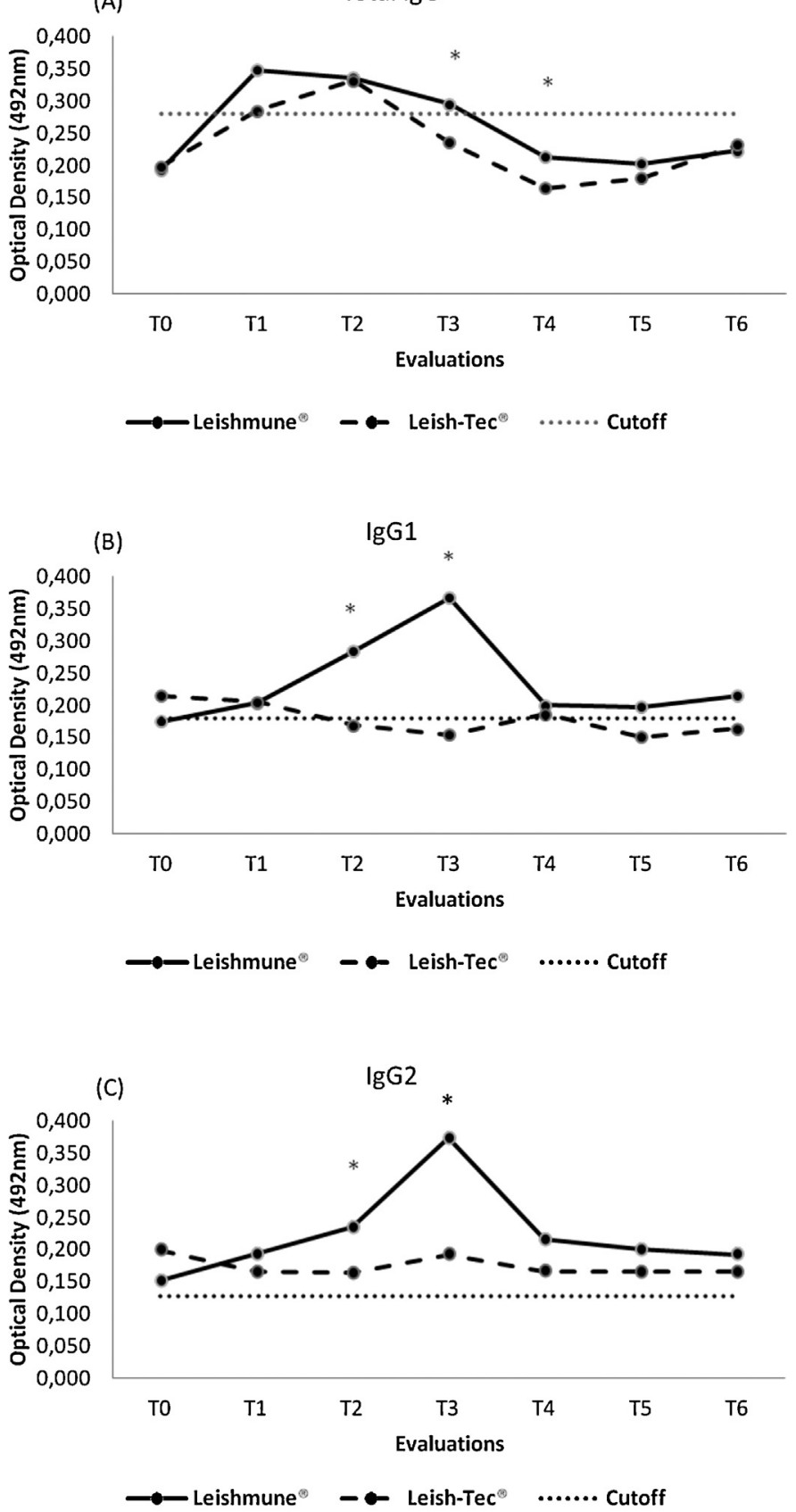

Fig. 1. Median values of the optical densities (ODs) for total IgG, IgG1, and IgG2 ((A), (B) and (C), respectively) measured by indirect ELISA from 75 dogs that were subjected to the complete vaccination protocol against visceral leishmaniasis with Leishmune ${ }^{\circledR}(\mathrm{G} 2, n=36)$ or Leish-Tec ${ }^{\circledR}(\mathrm{G} 3, n=39)$ vaccines, and remained uninfected after 11 months of follow-up. $T_{0}$-immediately before the first vaccine dose; $T_{1}$-immediately before the second dose (21 days); $T_{2}$-immediately before the third dose (42 days); $T_{3}-21$ days after the third dose; $T_{4}-90$ days after $T_{3} ; T_{5}-180$ days after $T_{3}$; and $T_{6}-270$ days after $T_{3}$. Cut off value $=0.280$. The asterisks indicate significant differences between vaccine outcomes ( $p<0.05$, Mann-Whitney test). Graphics by GraphPad Prism v 5.0 for Windows (GraphPad Software, USA).

was 59.5\% (25/42) and 54.8\% (23/42), respectively. During followup, the dogs that received Leishmune ${ }^{\circledR}$ had higher total IgG values than those vaccinated with Leish-Tec ${ }^{\circledR}$, with significant differences at $T_{3}(p=0.023)$ and $T_{4}(p=0.005)$, respectively at 21 and 90 days after the immunization protocols had been completed (Fig. 1A). The ELISA OD values of $\operatorname{IgG} 1$ and $\operatorname{IgG} 2$ in the Leishmune ${ }^{\circledR}$ group were higher than those of Leish-Tec ${ }^{\circledR}$ dogs; statistically significant differences were found for both the reactivity of IgG1 at $T_{2}(p=0.003)$ and
$T_{3}(p<0.001)$, and of $\operatorname{IgG} 2$ at $T_{2}$ and $T_{3}(p<0.001)$ between groups (Fig. $1 \mathrm{~B}$ and $\mathrm{C}$ ).

The distribution of individual OD values for serum IgG, IgG1and $\operatorname{IgG} 2$ in the dogs vaccinated with Leishmune ${ }^{\circledR}$ or Leish-Tec ${ }^{\circledR}$ are shown in Fig. 2. The OD values of total IgG were similar between dogs vaccinated with either vaccine, increasing from the first dose up to 21 days after the third dose $\left(T_{3}\right)$ (Fig. 2A). There was a marked dispersion in serum IgG1 and IgG2 OD values of Leishmune ${ }^{\circledR}$ vaccinated dogs at $T_{3}$, which characterized the peak reactivity of these subclasses (Fig. 2B and C).

In the last evaluation in the 11th month of follow-up $\left(T_{6}\right), 32.5 \%$ $(13 / 40)$ and $30.9 \%(13 / 42)$ of the dogs vaccinated with Leishmune ${ }^{\circledR}$ and Leish-Tec ${ }^{\circledR}$, respectively, showed OD values above the cutoff value of the ELISA for total IgG detection (Table 4). Of the nine dogs that formerly presented with borderline $\operatorname{IgG}$ values $(\mathrm{OD}=0.224$ to 0.336 ), four (2/5 Leishmune ${ }^{\circledR}$ 's and $2 / 4$ Leish-Tec ${ }^{\circledR}$ 's) became seropositive at $T_{6}$, whereas four (3/5 Leishmune ${ }^{\circledR}$ 's and $1 / 4$ Leish$\operatorname{Tec}^{\circledR}$ 's) remained borderlines, and one (1/4 Leish-Tec ${ }^{\circledR}$ 's) became seronegative (Table 5).

All naturally infected control dogs (G1) presented high antibody reactivity, reaching average OD values of $1.760,1.446$, and 1.453 for total $\operatorname{IgG}$, IgG1, and $\operatorname{IgG} 2$, respectively, and significantly different $(p<0.001)$ from those of vaccinated dogs in every evaluation (Table 1).

The serology results of seven vaccinated dogs that became positive in spleen culture or PCR during follow-up are listed in Table 3, showing that three dogs were seropositive, two remained seronegative and two were borderlines for IgG values.

\subsection{Infection and transmission rates}

Splenic biopsies were performed in 36 out of the 45 dogs from $\mathrm{G} 2$, in 34 out of 46 dogs from G3, and in all 9 dogs from G4. Xenodiagnosis was performed in 34 out of 45 dogs from G2, in 33 out of 46 dogs from G3, and all 9 dogs from G4. The aggressive behavior of some animals prevented the performance of such lengthier procedures in field conditions. Parasites were detected in splenic cultures and/or PCR from $11.1 \%$ of G2 (4/36), $8.8 \%$ of G3 (3/34), and $11.1 \%$ of G4 animals (1/9) (Tables 3 and 5 ).

The xenodiagnosis was positive in one dog from G2 (1/34), two dogs from G3 (2/33), and one from G4 (1/9). This mean that 5.1\% (2/39) of dogs vaccinated with Leishmune ${ }^{\circledR}$ and $5.4 \%$ (2/37) of dogs vaccinated with Leish-Tec ${ }^{\circledR}$ became infectious to the phlebotomine vector of LVC (Tables 3 and 5).

The naturally infected control dogs (G1) exhibited infectiousness of $36.6 \%(11 / 30)$ and a positive correlation between parasitic detection, signs of CVL, and infectivity to phlebotomines.

\section{Discussion}

Our prospective clinical study performed in field conditions shows that vaccination of dogs with Leishmune ${ }^{\circledR}$ or Leish-Tec ${ }^{\circledR}$ accomplished in similar results with respect to clinical aspects, parasitism, IgG seropositivity and dog infectiousness. However, in the present study the frequency and severity of adverse reactions were quite different from those reported in the literature for either product $[11,14]$. Although both Leishmune ${ }^{\circledR}$ and Leish-Tec ${ }^{\circledR}$ induced adverse reactions in immunized animals, the dogs that received Leish-Tec ${ }^{\circledR}$ had more and stronger local and systemic adverse reactions compared with dogs from the Leishmune ${ }^{\circledR}$-vaccinated group, in which only one animal presented mild local reactions. Differently, other authors have described reactions including local pain, anorexia, lethargy, local edema, vomiting, and diarrhea, in dogs vaccinated with Leishmune ${ }^{\circledR}[11]$. Our results also contradict at least one study that described the absence of adverse reactions 
Table 4

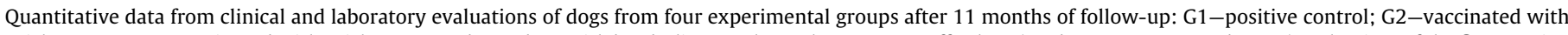

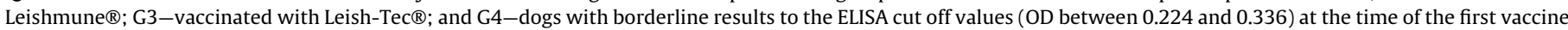
injection.

\begin{tabular}{|c|c|c|c|c|c|c|c|}
\hline & \multicolumn{3}{|c|}{ Leishmune® } & \multicolumn{3}{|c|}{ Leish-Tec $®$} & \multirow{2}{*}{$\begin{array}{l}\text { Positive control } \\
\text { G1 } n=30\end{array}$} \\
\hline & $\mathrm{G} 2 n=40$ & G4 $n=5$ & Total $n=45$ & G3 $n=42$ & $\mathrm{G} 4 n=4$ & Total $n=46$ & \\
\hline Adverse reactions & 1 & 0 & 1 & 6 & 0 & 6 & - \\
\hline Clinical signs & 3 & 1 & 4 & 3 & 0 & 3 & 30 \\
\hline Seroconversion $\left(T_{6}\right)$ & 13 & 2 & 15 & 13 & 2 & 15 & $30^{\mathrm{a}}$ \\
\hline Parasitism in spleen (culture and/or PCR) & $4 / 36^{b}$ & $1 / 5$ & $5 / 41^{b}$ & $3 / 34^{b}$ & $0 / 4$ & $3 / 38^{b}$ & 30 \\
\hline Xenodiagnosis & $1 / 34^{\mathrm{b}}$ & $1 / 5$ & $2 / 39^{b}$ & $2 / 33^{\mathrm{b}}$ & $0 / 4$ & $2 / 37^{b}$ & 11 \\
\hline
\end{tabular}

a G1 was not monitored, and all results are from a single evaluation.

b Number of positive animals/number of evaluated animals.

in dogs vaccinated with Leish-Tec ${ }^{\circledR}$ [14]. Adverse reactions have been attributed to adjuvants. Saponin-dependent toxic effects are known to vary depending on the purity of the compound and the dosage used. Despite the fact that both vaccines contains the same dose of saponin in their composition, Leishmune ${ }^{\circledR}$ is formulated with the purified fraction QS21 [29], which induces milder toxic effects [30,31] and is known to be extracted from the Riedel de Haen, the saponin that composes the Leish-Tec ${ }^{\circledR}$ vaccine [14]. In general we observed that either, occurrence and severity of adverse reactions increased according to the number of vaccine booster injections. Because vaccine components act as immune potentiators, it is possible that a higher frequency of vaccine exposure results in greater systemic and/or local adverse effects [32]. Nevertheless, no significant differences were found between vaccine reactogenicity related to gender, breed or age in the present study.

A virtually identical proportion of dogs immunized with Leishmune ${ }^{\circledR}$ or Leish-Tec ${ }^{\circledR}$ remained clinically healthy through to the end of the 44 weeks of follow-up in the CVL endemic area. Similar rates of clinical outcome in dogs immunized with Leishmune ${ }^{\circledR}$, such as 92\% [9], 95\% [10], and $83.3 \%$ [33] have been reported in other studies. Results of clinical follow up in dogs after Leish-Tec ${ }^{\circledR}$ vaccination reported in the literature cannot be compared to those obtained in our study, because the number of dogs was smaller, they were challenged by experimental infection with living parasites and placed in laboratory cages [14]. Thus, the finding that $92.8 \%$ of the dogs that continued healthy for 11 months after being vaccinated with Leish-Tec ${ }^{\circledR}$ in our study is unprecedented, because the animals were maintained at home in the endemic area, thus exposed to parasite transmission by phlebotomines in natural conditions.

Infected dogs can remain healthy [25], but the laboratory techniques used to detect infection might define them as possible reservoirs [34]. However, in our study, animals without clinical signs of CVL were not capable of transmitting parasites to phlebotomines by xenodiagnosis. This finding corroborates the results of other authors, which have demonstrated that clinically healthy dogs also present an efficient immune response against the parasite, characterized by discrete or absent antibody detection values, low parasitic loads, and little or no ability to transmit Leishmania to the vector $[35,36]$.

Serology evaluation of positive control dogs with clinical evidence of CVL showed that IgG and subclasses of IgG OD values were significantly higher than those of the vaccinated groups, even the dogs that became naturally infected during the follow-up. However, the majority of dogs vaccinated with either product showed anti-Leishmania IgG positivity by ELISA during and up to 21 days after receiving the three-dose protocol in our study. Similarly, seroconversion has been reported after vaccination of dogs with Leishmune ${ }^{\circledR}$ [37]. Nevertheless, our seropositivity findings indicate that immunized animals with either vaccine may become serologically diagnosed CVL positive. Culling of seropositive dogs is one of the main recommendations of public health authorities to control VL in endemic areas in Brazil. Consequently, vaccinated animals that become serologically positive can be unnecessarily euthanized. Therefore, a major problem with vaccination is the potential of vaccines to induce antibody responses that react with Leishmania antigens. This issue has motivated studies using different antigens, such as FML $[9,10,38,39]$ or different soluble Leishmania antigen $[33,37]$ for distinguishable serology. The conclusions drawn in these reference studies emphasize that so far it is not possible to distinguish vaccinated dogs from naturally infected ones by the routine protocols [40]. The rates of seroconversion that we found in the dogs during the different points of follow-up after immunization with Leish-Tec ${ }^{\circledR}$ are also unprecedented as there is no study reporting similar findings in the literature, as far as we know. By contrast, in a study using seven dogs immunized with Leish-Tec ${ }^{\circledR}$, no seroconversion post-immunization was observed by the authors [14], probably due to the small number of tested

Table 5

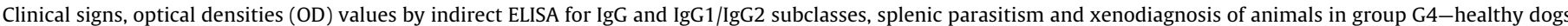

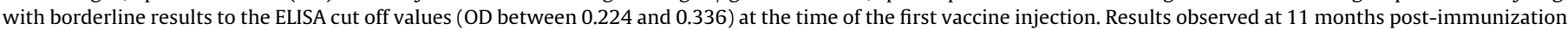

\begin{tabular}{|c|c|c|c|c|c|c|c|c|c|}
\hline \multirow[t]{2}{*}{ Animal } & \multirow[t]{2}{*}{ Vaccine } & \multirow[t]{2}{*}{ Clinical Signs } & \multirow[t]{2}{*}{$\operatorname{IgG}(\mathrm{OD})$} & \multirow[t]{2}{*}{ Result $^{\mathrm{a}}$} & \multirow[t]{2}{*}{$\operatorname{IgG1}(\mathrm{OD})^{\mathrm{b}}$} & \multirow[t]{2}{*}{$\operatorname{IgG} 2(\mathrm{OD})^{\mathrm{b}}$} & \multicolumn{2}{|c|}{ Splenic parasitism } & \multirow[t]{2}{*}{ Xenodiagnosis } \\
\hline & & & & & & & Culture & PCR & \\
\hline 1 & Leishmune ${ }^{\circledR}$ & $\begin{array}{l}\text { Skin lesions, pale } \\
\text { mucous, splenomegaly }\end{array}$ & 1.103 & Positive & 0.385 & 0.792 & Positive & Positive & Positive \\
\hline 2 & Leishmune ${ }^{\circledR}$ & Absent & 0.308 & Borderline & 0.273 & 0.255 & Negative & Negative & Negative \\
\hline 3 & Leishmune ${ }^{\circledR}$ & Absent & 0.322 & Borderline & 0.165 & 0.099 & Negative & Negative & Negative \\
\hline 4 & Leishmune $₫$ & Absent & 0.330 & Borderline & 0.210 & 0.157 & Negative & Negative & Negative \\
\hline 5 & Leishmune ${ }^{\circledR}$ & Absent & 0.473 & Positive & 0.673 & 0.769 & Negative & Negative & Negative \\
\hline 6 & Leish-Tec® & Absent & 0.674 & Positive & 0.278 & 0.367 & Negative & Negative & Negative \\
\hline 7 & Leish-Tec $®$ & Absent & 0.312 & Borderline & 0.074 & 0.094 & Negative & Negative & Negative \\
\hline 8 & Leish-Tec ${ }^{\circledR}$ & Absent & 0.391 & Positive & 0.118 & 0.099 & Negative & Negative & Negative \\
\hline 9 & Leish-Tec $®$ & Absent & 0.216 & Negative & 0.137 & 0.333 & Negative & Negative & Negative \\
\hline
\end{tabular}

a Total IgG cut off of 0.280 was considered for serological diagnosis.

b Cut off values: 0.180 (IgG1); 0.128 (IgG2). 
(A)

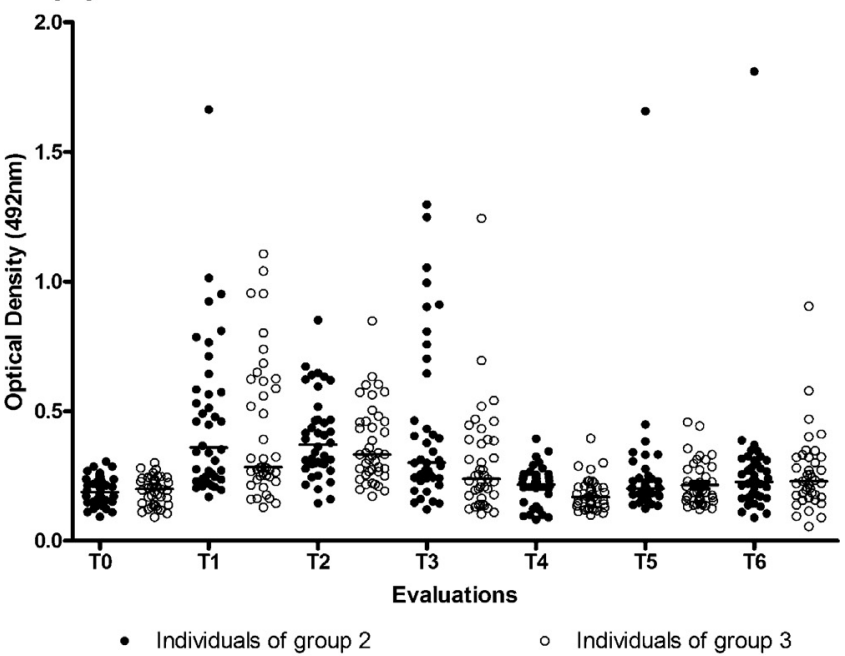

(B)

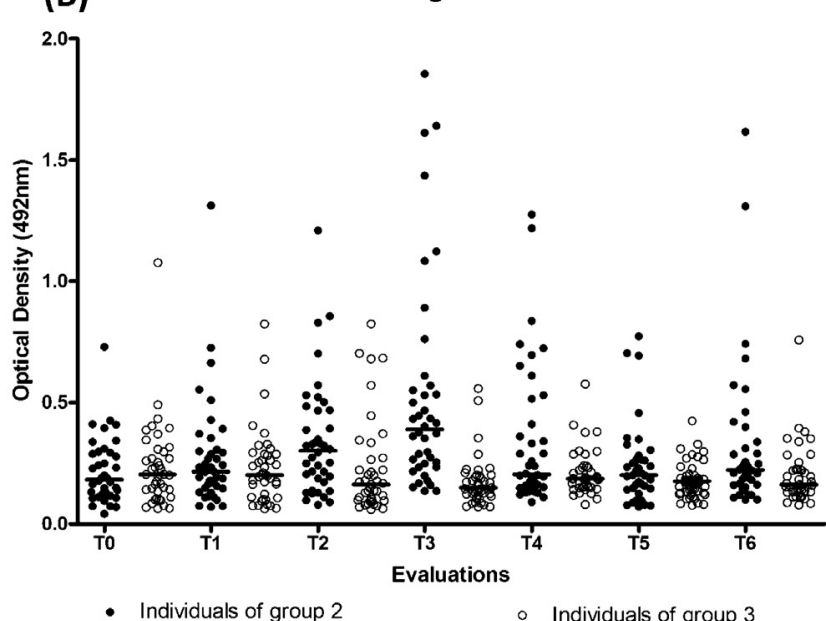

(C)

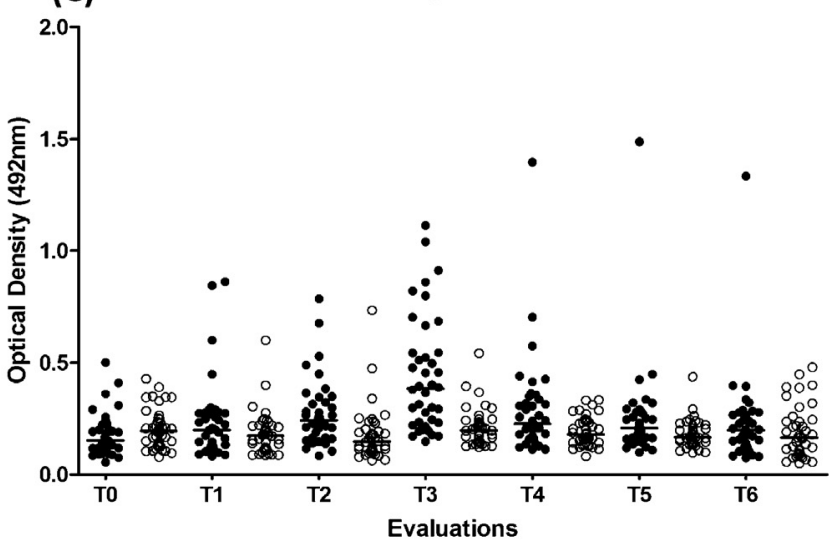

- Individuals of group 2

Individuals of group 3

Fig. 2. Individual optical density (OD) values by indirect ELISA for total IgG, IgG1, and IgG2 ((A), (B) and (C), respectively) from 82 dogs immunized with Leishmune ${ }^{\circledR}$ $(\mathrm{G} 2, n=40)$ or Leish-Tec ${ }^{\circledR}(\mathrm{G} 3, n=42)$ vaccines. $T_{0}$-day of the first vaccine dose; $T_{1}$-immediately before the second dose ( 21 days); $T_{2}$-immediately before the third dose (42 days); $T_{3}-21$ days after the third dose; $T_{4}-90$ days after $T_{3} ; T_{5}-180$ days after $T_{3}$; and $T_{6}-270$ days after $T_{3}$. Graphics by GraphPad Prism v 5.0 for Windows (GraphPad Software, USA). dogs. Our findings of lower antibody reactivity of the Leish-Tec ${ }^{\circledR}$ group compared to the Leishmune ${ }^{\circledR}$ dogs may be attributed to the different antigenic composition between vaccines. Probably the rA2 antigen of Leish-Tec ${ }^{\circledR}$ may induce a less strong humoral response [12-14] in comparison with the response triggered by FML antigen of Leishmune ${ }^{\circledR}$ in dogs [18]. Nevertheless, in our study, the outcome of $32.5 \%$ and $30.9 \%$ of vaccinated dogs that exhibited seroconversion at the end of our follow-up falls within the range of seropositivity results reported by other authors in dogs in the same endemic area during the same period $[20,41]$.

No proportional relationships in the $\operatorname{IgG} / \operatorname{IgG} 1 / \operatorname{IgG} 2$ reactivity observed in our study would distinguish the groups of vaccinated dogs, neither the dogs that had been vaccinated from dogs with natural active infection. The literature also indicates that there is no proportional correlation between the IgG subclasses reactivity and the clinical status of the animal [42-47]. Besides, attempts to use IgG1/IgG2 proportions to distinguish vaccinated from infected dogs $[33,39]$ have been contradictory.

Our reason for selecting the spleen for parasite detection was based on the greater diagnostic sensitivity of such approach [48-51]. Although parasite isolation in culture is considered the reference standard for diagnosing Leishmania infection, the sensitivity of this method is variable [52] and proportional to the host parasitic load $[51,53]$. In order to assure a trustful evaluation of possible infections with lower parasite loads, we also subjected spleen samples to analysis by the more sensitive PCR technique $[34,54]$. We found only two Leishmune ${ }^{\circledR}$-vaccined and one LeishTec $^{\circledR}$-vaccinated dog positive in cultures. These three dogs had the highest IgG reactivities within their respective vaccine-group, and in comparison to the remaining six vaccinated dogs that were positive only by PCR. According to different authors, there is a correlation between higher parasite loads and greater IgG reactivity $[55,56]$. Thus, we assumed that the greater sensitivity of the PCR method allowed the detection of infection in animals that certainly harbored lower parasite loads.

After xenodiagnosis, the detection of Leishmania in phlebotomines was performed in the present study by PCR, a more sensitive method comparing with optical microscopy for parasite detecting [50]. Still, the CVL positive group showed a parasite to phlebotomine transmission rate of only $36.6 \%$ by xenodiagnosis. This result indicates that even with the confirmed presence of parasites in the body, a dog will not always be an effective transmitter of parasites to L. longipalpis. Yet, the infectiousness was far lower and similar between Leishmune ${ }^{\circledR}$ - and Leish-Tec ${ }^{\circledR}$-vaccinated dogs in our study. Thus, both vaccines seem to have induced an appreciable degree of protection for infectiousness, considering that the immunized dogs stayed in an area which is considered highly endemic [57].

It should be emphasized that this study is the first report that used xenodiagnosis to evaluate vaccine efficacy in a prospective study using domiciled dogs maintained under natural infection exposure in endemic areas of VL. Previously, the transmission rate has been evaluated for the Leishmune ${ }^{\circledR}$, but based on skin immunohistochemistry [58], or the feeding of phlebotomines in artifacts composed of bird skin [18]. Another study also evaluated Leishmune ${ }^{\circledR}$ efficacy assessed by xenodiagnosis in dogs, but captive in experimental kennels in endemic areas [33]. As far as we know, this is the first report that evaluated Leish-Tec ${ }^{\circledR}$ efficacy using xenodiagnosis.

The nine formerly borderline dogs may have been infected during the 3-4 weeks lapse between the screening and the first vaccine injection, due to operational difficulties inherent to field work. Studies show that naturally resistant dogs may present serology results in the 'gray zone' [59]. Our data indicate that even with the possibility of previous contact with Leishmania at the beginning of vaccination, most of these dogs remained healthy and did not 
transmit parasites to the vector as assessed by negativity results in xenodiagnosis. Additionally, one of them became seronegative at the end of the monitoring. Consistent with descriptions that have been stressed by several authors, the only former borderline dog that transmitted Leishmania to the vector assessed by xenodiagnosis also presented clinical signs of CVL, presence of parasites in the splenic aspirate culture, and yet the highest IgG reactivity within the group. The rate of splenic parasitism in the formerly borderline group was within the range of that of both groups of formerly negative dogs, end even equal to the positivity of the Leishmune ${ }^{\circledR}$ vaccinated dogs. Thus, the outcome of Leishmune ${ }^{\circledR}$ or Leish-Tec ${ }^{\circledR}$ vaccination of borderline and seronegative dogs was similar.

It is important to take into account that all vaccinated dogs were studied in natural conditions, living in households in the endemic area, thus, possible differences in the nutritional state of the animals housed in the different places could have influenced the greater or lesser susceptibility and/or resistance to Leishmania infection.

\section{Conclusions}

There were no significant differences in the rates of seroconversion, clinical signs, parasitism, and parasite transmission to the vector by xenodiagnosis among the dogs immunized with the Leishmune ${ }^{\circledR}$ or Leish-Tec ${ }^{\circledR}$ vaccines during natural exposure to infection for eleven months in a VL endemic area. Animals immunized with Leishmune ${ }^{\circledR}$ presented higher IgG, IgG1 and $\operatorname{IgG} 2$ humoral reactivity by ELISA. The dogs immunized with Leish-Tec ${ }^{\circledR}$ exhibited higher frequency and intensity of adverse reactions.

\section{Authorship}

CBF and SMBM accomplished the study, drafted and finished the manuscript. JTMJ and $\mathrm{CJ}$ helped with the xenodiagnosis and parasitological tests. DFL and helped with the clinical and immunological methods. BMPSS helped with the molecular tests. DBMF and PSTV helped with the serological tests and statistical analysis of all data. SMBM planned, supervised, and obtained the funds for the development of the study. All authors have reviewed the manuscript.

\section{Conflicts of interest statement}

There is no conflict of interests.

\section{Acknowledgements}

This work was supported by the Brazilian Public Agencies for National Research and Development, the National Council for Scientific and Technological Development (CNPq-Proc. N. 307475/2008-5 and 479753/2009-1) and Bahia Research Foundation (FAPESB-Ped. N. 4749/2009). We thank to CAPES, the Brazilian coordination for improvement of higher education personnel, for the MSc degree scholarship (C.B. Fernandes). We thank to Dr. Lain Pontes-de-Carvalho (FIOCRUZ-BA-Brazil) for the constructive criticism on data and inspiring observations.

\section{Appendix A. Supplementary data}

Supplementary data associated with this article can be found, in the online version, at http://dx.doi.org/10.1016/j.vaccine. 2013.12.046.

\section{References}

[1] WHO. World Health Organization. http://www.who.int/leishmaniasis/ burden/magnitude/burden_magnitude/en/index.html (accessed: 07.01.14).

[2] WHO. Report on neglected tropical diseases. World Health Organization; 2012, http://www.who.int/neglected_diseases/2012/report/en/index.htme (accessed: 15.09.12)

[3] Kuhls K, Alam MZ, Cupolillo E, Ferreira GEM, Mauricio IL, Oddone R, et al. Comparative microsatellite typing of New World Leishmania infantum reveals low heterogeneity among populations and its recent Old World origin. PLoS Negl Trop Dis 2011;5:1-16.

[4] Ministério da Saúde[[nl]]Ministry of Health of Brazil. Portal da saúde SUS-Sinan/SVS/MS. Brazil: Ministério da Saúde[[nl]]Ministry of Health of Brazil; 2012, http://portal.saude.gov.br/portal/arquivos/pdf/ 2012_11_casos_de_lv_entre_1990_e_2011_final.pdf (accessed: 14.12.12).

[5] Maia-Elkhoury AN, Alves WA, Sousa-Gomes ML, Sena JM, Luna EA. Visceral leishmaniasis in Brazil: trends and challenges. Cad Saud Publica 2008;24:2941-7.

[6] Courtenay O, Quinnell RJ, Garcez LM, Shaw JJ, Dye C. Infectiousness of a cohort of Brazilian dogs: why culling fails to control visceral leishmaniasis in areas of high transmission. J Infect Dis 2002;186:1314-20.

[7] Dye C. The logic of visceral leishmaniasis control. Am J Trop Med Hyg 1996;55:125-30

[8] Alvar J, Canavate C, Molina R, Moreno J, Nieto J. Canine leishmaniasis. Adv Parasitol 2004;57:1-88.

[9] da Silva VO, Borja-Cabrera GP, Correia Pontes NN, de Souza EP, Luz KG, Palatnik $\mathrm{M}$, et al. A phase III trial of efficacy of the FML-vaccine against canine kalaazar in an endemic area of Brazil (São Gonçalo do Amarante, RN). Vaccine 2001;19:1068-78.

[10] Borja-Cabrera GP, Correia Pontes NN, da Silva VO, de Souza EP, Santos WR, Gomes EM, et al. Long lasting protection against canine kala-azar using the FMLQuilA saponin vaccine in an endemic area of Brazil (São Gonçalo do Amarante). Vaccine 2002;20:3277-84.

[11] Parra LE, Borja-Cabrera GP, Santos FN, Sousa LO, Palatnik-de-Sousa CB, Menz I Safety trial using the Leishmune ${ }^{\circledR}$ vaccine against canine visceral leishmaniasis in Brazil. Vaccine 2007;25:2180-6.

[12] Coelho EA, Tavares CA, Carvalho FA, Chaves KF, Teixeira KN, Rodrigues RC et al. Immune responses induced by the Leishmania (Leishmania) donovani A2 antigen, but not by the LACK antigen, are protective against experimental Leishmania (Leishmania) amazonensis infection. Infect Immun 2003;71:3988-94.

[13] Zanin FH, Coelho EA, Tavares CA, Marques-Silva EA, Silva-Costa MM, Rezende $\mathrm{SA}$, et al. Evaluation of immune responses and protection induced by A2 and nucleoside hydrolase (NH) DNA vaccines against Leishmania chagasi and Leishmania amazonensis experimental infections. Microb Infect 2007;9:1070-7.

[14] Fernandes AP, Costa MMS, Coelho EAF, Michalick MSM, Freitas E, Melo MN et al. Protective immunity against challenge with Leishmania (Leishmania) chagasi in beagle dogs vaccinated with recombinant A2 protein. Vaccine 2008;26:5888-95.

[15] Ministério da Saúde, Ministério da Agricultura, Pecuária e Abastecimento Instrução normativa interministerial no. 31, 2009, M.A.P.A.; Brasil, Nota de Esclarecimento sobre as Vacinas Antileishmaniose Visceral Canina registradas no M.A.P.A., http://www.agricultura.gov.br/arq_editor/file/Aniamal/ Registros_Atorizacoes/Produtos_veterinarios/Comunicacoes_e_instrucoes tecnicas/Nota_de_esclarecimento_sobre_a_vacina.pdf (accessed: 07.01.14).

[16] Ministério da Saúde. Secretaria de Vigilância em Saúde, Brasil. Nota técnica vacina anti-leishmaniose visceral canina Leishmune ${ }^{\circledR}$. http://portal.saude. gov.br/portal/arquivos/pdf/leishimune_nota_tecnica.pdf. (accessed: 15.09.11).

[17] Ministério da Agricultura, Pecuária e Abastecimento, Brasil. Instrução Normativa Interministerial $n^{\circ}$ 31. Regulamento Técnico para Pesquisa, Desenvolvimento, Produção, Avaliação, Registro e Renovação de Licenças, Comercialização e Uso de Vacina Contra a Leishmaniose Visceral Canina. http:// sistemasweb.agricultura.gov.br/sislegis/action/detalhaAto.do? method= visualizarAtoPortalMapa\&chave=815005048 (accessed: 06.06. 11).

[18] Saraiva EM, Figueiredo BA, Santos FN, Borja-Cabrera GP, Nico D, Souza LO, et al. The FML-vaccine (Leishmune ${ }^{\circledR}$ ) against canine visceral leishmaniasis: a transmission blocking vaccine. Vaccine 2006;24:2423-31.

[19] Barboza DCPM, Gomes Neto CMB, Leal DC, Bittencourt DVV, Carneiro AJB, Souza BMPS, Oliveira LS, Julião FS, Souza VMM, Franke CR. Cohort study in areas at risk for canine visceral leishmaniasis in municipalities of the metropolitan region of Salvador, Bahia. Braz Rev Bras Saude Prod Anim 2006;7:152-63.

[20] Bastos LA, Bordoni MG, Solcá MS, Silva MMN, Pereira GC, Santos WLC, Veras PST, Bavia ME, Fraga DBM. Distribuição da leishmaniose visceral canina no município de Camaçari, Bahia. In: XXVII Reunião de Pesquisa Aplicada em Doença de Chagas e XV Reunião de Pesquisa Aplicada em Leishmanioses. Uberaba: Universidade Federal do Triângulo Mineiro; 2011.

[21] IBGE. Instituto Brasileiro de Geografia e Estatística. http://cidades.ibge.gov.br/ xtras/uf.php?lang=\&coduf=29\&search=bahia (acessed: 07.01.14).

[22] Presidência da República do Brasil. LEI 11.794/2008 (LEI ORDINÁRIA) 08.10.2008. Disponível em: http://www.planalto.gov.br/ccivil_03/_ato20072010/2008/lei/111794.htm (accessed: 07.01.14).

[23] Fort Dodge Saúde Animal Ltda[[nl]]Fort Dodge Animal Health. Manual técnico vacina Leishmune [Leishmune vaccine, technical manual]. Fort Dodge: Fort Dodge Saúde Animal Ltda[[nl]]Fort Dodge Animal Health; 2004. p. 51.

[24] Hertape Callier Saúde Animal Ltda[[nl]]Hertape Callier Animal Health. Manual técnico vacina Leish-Tec [Leish-Tec vaccine, technical manual]. Hertape Callier: 
Hertape Callier Saúde Animal Ltda[[nl]]Hertape Callier Animal Health; 2008. p. 76.

[25] Solano-Gallego L, Koutinas A, Miro G, Cardoso L, Pennisi MG, Ferrer L, et al. Directions for the diagnosis, clinical staging, treatment and prevention of canine leishmaniosis. Vet Parasitol 2009;165:1-18.

[26] Barrouin-Melo SM, Larangeira DF, de Andrade Filho FA, Trigo J, Juliao FS, Franke CR, et al. Can spleen aspirations be safely used for the parasitological diagnosis of canine visceral leishmaniosis? A study on asymptomatic and polysymptomatic animals. Vet J 2006;171:331-9.

[27] Paranhos-Silva M, Freitas LAR, dos-Santos WLC, Grimaldi L, Pontes-de-Carvalho L, Oliveira-dos-Santos AJ. A cross-sectional serodiagnostic survey of canine leishmaniasis due to Leishmania chagasi. Am J Trop Med Hyg 1996;51:39-44.

[28] Zwirner NW. ELISA. In: Margni RA, editor. Imunología e imunoquímica. 5th ed Buenos Aires: Editorial Médica Panamericana; 1996. p. 798-820, 976 p.

[29] Oliveira-Freitas E, Casas CP, Borja-Cabrera GP, Santos FN, Nico D, Souza LOP, et al. Acylated and deacylated saponins of Quillaja saponaria mixture as adjuvants for the FML-vaccine against visceral leishmaniasis. Vaccine 2006;24:3909-20.

[30] Kensil CR, Patel U, Lennick M, Marciani DJ. Separation and characterization of saponins with adjuvant activity from Quillaja saponaria Molina cortex. J Immunol 1991;146:431-7.

[31] Santos WR, de Lima VMF, de Souza EP, Bernardo RR, Palatnik M, Palatinik-deSousa CB. Saponins, IL12 and BCG adjuvant in the FML-vaccine formulation against murine visceral leishmaniasis. Vaccine 2002;21:30-43.

[32] Moore GE, Hogenesch H. Adverse vaccinal events in dogs and cats. Vet Clin N Am Small Anim Pract 2010;40:393-407.

[33] de Amorim IFG, Freitas E, Alves CF, Tafuri WL, Melo MN, Michalik MSM, et al. Humoral immunological profile and parasitological statuses of Leishmune ${ }^{\circledR}$ vaccinated and visceral leishmaniasis infected dogs from an endemic area. Vet Parasitol 2010;173:55-63.

[34] Lachaud L, Chabbert E, Dubessay P, Dereure J, Lamothe J, Dedet JP, et al. Value of two PCR methods for the diagnosis of canine visceral leishmaniasis and the detection of asymptomatic carriers. Parasitology 2002;125:197-207.

[35] Dye C, Killick-Kendrick R, Vitutia M, Walton R, Killick-Kendrick M, Harith A, et al. Epidemiology of canine leishmaniasis: prevalence, incidence and basic reproduction number calculated from a cross-sectional serological survey on the island of Gozo, Malta. Parasitology 1992;105:35-44.

[36] Verçosa B, Lemos C, Mendonça I, Silva S, de Carvalho S, Goto H, et al. Transmission potential, skin inflammatory response, and parasitism of symptomatic and asymptomatic dogs with visceral leishmaniasis. BMC Vet Res 2008;4:45.

[37] Marcondes M, Ikeda FA, Vieira RF, Day MJ, Lima VM, Rossi CN, et al. Temporal IgG subclasses response in dogs following vaccination against Leishmania with Leishmune $^{\circledR}$. Vet Parasitol 2011;181:153-9.

[38] Borja-Cabrera GP, da Silva VO, da Costa RT, Reis AB, Mayrink W, Genaro O, et al. The fucose-manose ligand-ELISA in the diagnosis and prognosis of canine visceral leishmaniasis in Brazil. Am J Trop Med Hyg 1999;61:296-301.

[39] Mendes CO, de Souza EP, Borja-Cabrera GP, Batista LMM, dos Santos MA, Parra LE, et al. IgG1/IgG2 antibody dichotomy in sera of vaccinated or naturally infected dogs with visceral leishmaniosis. Vaccine 2003;21:2589-97.

[40] Marcondes M, de Lima VM, de Araújo MF, Hiramoto RM, Tolezano JE, Vieira RF, Biondo AW. Longitudinal analysis of serological tests officially adopted by the Brazilian Ministry of Health for the diagnosis of canine visceral leishmaniasis in dogs vaccinated with Leishmune $\left({ }^{\circledR}\right)$. Vet Parasitol 2013;197:649-52.

[41] Bordoni MG, Merelles SL, Solcá MS, Borja LS, Santos LS, Santos LCS, Leite BMM, Guedes Junior JCO, Pereira GC, Bavia ME, Santos WLC, Veras PST, Fraga DBM. Identification of risk factors associated to canine visceral leishmaniasis in an endemic area of Bahia. In: XVIII international congress for tropical medicine and malaria and XLVIII congress of the Brazilian Society for Tropical Medicine, vol. 1. 2012. p. 452-3.

[42] Solano-Gallego L, Riera C, Roura X, Iniesta L, Gallego M, Valladares JE, et al. Leishmania infantum-specific IgG, IgG1 and IgG2 antibody responses in healthy and ill dogs from endemic areas. Evolution in the course of infection and after treatment. Vet Parasitol 2001;96:265-76.
[43] Quinnell RJ, Courtenay O, Garcez LM, Kaye PM, Shaw MA, Dye C, et al. IgG subclass responses in a longitudinal study of canine visceral leishmaniasis. Vet Immunol Immunopathol 2003;91:161-8.

[44] da Costa-Val AP, Cavalcanti RR, de Figueiredo GN, Marques MMS, Alexander B, Williams P, et al. Canine visceral leishmaniasis: relationships between clinical status, humoral immune response, haematology and Lutzomyia (Lutzomyia) longipalpis infectivity. Vet J 2007;174:636-43.

[45] Travi BL, Osorio EY, Saldarriaga OA, Cadena H, Tabares CJ, Peniche A, et al. Clinical, parasitologic, and immunologic evolution in dogs experimentally infected with sand fly-derived Leishmania chagasi promastigotes. Am J Trop Med Hyg 2009;81:994-1003.

[46] Boggiatto PM, Ramer-Tait AE, Metz K, Kramer EE, Gibson-Corley K, Mullin K, et al. Immunologic indicators of clinical progression during canine Leishmania infantum infection. Clin Vaccine Immunol 2010;17:267-73.

[47] Carson C, Quinnell RJ, Day MJ, Courtenay O. Comparison of monoclonal and polyclonal antibodies for the detection of canine IgG1 and IgG2, and associations with infection outcome in Leishmania infantum naturally infected dogs. Vet Immunol Immunopathol 2010;133:264-8.

[48] Barrouin-Melo SM, Larangeira DF, Trigo J, Aguiar PH, dos Santos WLC, Pontesde-Carvalho L. Comparison between splenic and lymph node aspirations as sampling methods for the parasitological detection of Leishmania chagasi infection in dogs. Mem Inst Oswaldo Cruz 2004;99:195-7.

[49] Madeira M, Schubach A, Schubach T, Pereira S, Figueiredo F, Baptista C, et al. Post mortem parasitological evaluation of dogs seroreactive for Leishmania from Rio de Janeiro. Braz Vet Parasitol 2006;138:366-7.

[50] Michalsky EM, Rocha MF, da Rocha Lima AC, França-Silva JC, Pires MQ Oliveira FS, et al. Infectivity of seropositive dogs, showing different clinical forms of leishmaniasis, to Lutzomyia longipalpis phlebotomine sand flies. Vet Parasitol 2007; $147: 67-76$

[51] Maia C, Ramada J, Cristovão JM, Goncalves L, Campino L. Diagnosis of canine leishmaniasis: conventional and molecular techniques using different tissues. Vet J 2009;179:142-4.

[52] Sundar S, Rai M. Laboratory diagnosis of visceral leishmaniasis. Clin Diagn Lab Immunol 2002;9:951-8.

[53] Sanchez MA, Diaz NL, Zerpa O, Negron E, Convit J, Tapia FJ. Organ-specific immunity in canine visceral leishmaniasis: analysis of symptomatic and asymptomatic dogs naturally infected with Leishmania chagasi. Am J Trop Med Hyg 2004;70:618-24.

[54] Berrahal F, Mary C, Roze M, Berenger A, Escoffier K, Lamouroux D, et al. Canine leishmaniasis: identification of asymptomatic carriers by polymerase chain reaction and immunoblotting. Am J Trop Med Hyg 1996;55:273-7.

[55] Reis AB, Teixeira-Carvalho A, Vale AM, Marques MJ, Giunchetti RC, Mayrink $\mathrm{W}$, et al. Isotype patterns of immunoglobulins: hallmarks for clinical status and tissue parasite density in Brazilian dogs naturally infected by Leishmania (Leishmania) chagasi. Vet Immunol Immunopathol 2006;112:102-16.

[56] Teixeira-Neto RG, Giunchetti RC, Carneiro CM, Vitor RWA, Coura-Vital W, Quaresma PF, et al. Relationship of Leishmania-specific IgG levels and IgG avidity with parasite density and clinical signs in canine leishmaniasis. Vet Parasitol 2010;169:248-57 [57].

[57] Macedo BM, Bordoni M, Merelles SL, Solcá MS, Borja LS, Santos LCS, Guedes Jr JCO, Pereira GC, Dos-Santos WLC, Almeida MCC, Veras PST, Fraga DBM. Identification of clinical predictors signs for canine visceral leishmaniasis. In: Worldleish 5-fifth world congress on leishmaniasis, vol. 1. 2013. p. 526. Abstract Book.

[58] Nogueira FS, Moreira MA, Borja-Cabrera GP, Santos FN, Menz I, Parra LE, et al. Leishmune ${ }^{\circledR}$ vaccine blocks the transmission of canine visceral leishmaniasis: absence of Leishmania parasites in blood, skin and lymph nodes of vaccinated exposed dogs. Vaccine 2005;23:4805-10.

[59] Andrade PP, Reis AB, Gontijo FMC, Braga BL, Rocha RDR, Araujo MSS, et al. Clinical value of anti-Leishmania (Leishmania) chagasi IgG titers detected by flow cytometry to distinguish infected from vaccinated dogs. Vet Immunol Immunopathol 2007;116:85-7. 